\title{
Konsep Amanah dalam Perspektif Pendidikan Islam
}

\author{
Iwan Hermawan \\ Universitas Singaperbangsa Karawang \\ iwan.hermawan@staff.unsika.ac.id \\ Nurwadjah Ahmad \\ Universitas Islam Negeri Sunan Gunung Djati Bandung \\ Andewi Suhartini \\ Universitas Islam Negeri Sunan Gunung Djati Bandung
}

Naskah diterima: 9 Mei 2020 | Disetujui: 9 Agustus 2020| Diterbitkan: 9 September 2020

\begin{abstract}
Amanah is one of the most basic things for human beings as caliphs to have good social relations. It can also be said to be a professional attitude towards what God has given to all types of human professions. The purpose of this study is to examine the concept of amanah based on the Qur'an and Hadith in the perspective of Islamic education. The method used in this study is literature research on some books of Tafsir and Hadith. The result of this study is that amanah in question is the human obligation to seek knowledge and convey it, as stated in some verses in the Qur'an and Hadiths that state the importance of knowledge and convey it as part of carrying out amanah. Thus, Islamic education as a process of transformation of knowledge, is not only a process of seeking and imparting knowledge, but also an amanah that must be maintained and delivered, so that human beings have noble morals and good beliefs before God.
\end{abstract}

Keywords: Al-Qur'an, Concept of Amanah, Hadith, Islamic Education.

\begin{abstract}
Abstrak
Amanah adalah salah satu hal yang paling mendasar bagi manusia sebagai khalifah untuk melakukan hubungan sosial dengan lingkungan hidupnya. Amanah dapat juga dikatakan sebagai wujud sikap profesional terhadap apa yang sudah diberikan Allah terhadap semua jenis profesi manusia. Tujuan penelitian ini adalah mengkaji konsep amanah berdasarkan pada Al-Qur'an dan Hadis dalam perspektif pendidikan Islam. Metode yang digunakan dalam penelitian ini adalah riset pustaka terhadap beberapa kitab Tafsir dan kitab Hadis. Hasil kajian dari penelitian ini adalah bahwa amanah yang dimaksud adalah kewajiban manusia untuk mencari ilmu dan menyampaikannya, sebagaimana tercantum dalam beberapa ayat dalam Al-Qur'an dan beberapa Hadis yang menyatakan pentingnya ilmu pengetahuan dan menyampaikannya sebagai bagian dari menjalankan amanah. Dengan demikian, pendidikan Islam sebagai kesatuan proses transformasi ilmu pengetahuan, bukan hanya sekedar proses mencari dan menyampaikan ilmu, namun merupakan amanah yang harus dijaga dan disampaikan, agar manusia mempunyai akhlak yang mulia, beriman, dan bertakwa kepada Allah.
\end{abstract}

Kata Kunci: Al-Qur'an, Hadis, Konsep Amanah, Pendidikan Islam. open access article under the CC BY-SA 4.0 license. DOI: 10.37680/qalamuna.v12i2.389 


\section{Pendahuluan}

Amanah merupakan permasalahan yang sentral dalam Al-Qur'an, karena pada dasarnya perintah dan larangan Allah merupakan amanah untuk manusia dan seluruh makhluk ciptaan-Nya. Amanah merupakan dasar utama dalam segala aktifitas ibadah maupun muamalah dalam penghambaan diri kepada Allah, karena dengan amanah itulah manusia melakukan aktifitas dari semua perintah dan larangan dari Allah sebagaimana tercantum dalam Q.S. Adh-Dhariyat: 56.

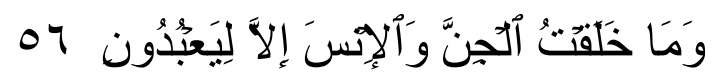

Artinya: "Dan aku tidak menciptakan jin dan manusia melainkan supaya mereka mengabdi kepada-Ku."

Mengabdi berarti perintah untuk melaksanakan ibadah sebagai balasan dari nikmat-nikmat Allah yang sudah diberikan. Di sinilah Allah menjuruskan hidup makhluk-Nya dan memberi pengarahan. Allah menciptakan jin dan manusia tidak untuk yang lain, hanya untuk satu macam tugas saja, yaitu mengabdi dan beribadah. Beribadah yaitu "mengakui bahwa kita ini hamba-Nya, tunduk kepada kemauan-Nya" (Hamka, 1982, p. 6928). Menurut Ibnu Katsir, "mereka diperintahkan beribadah, bukan karena Allah membutuhkan mereka” (Al-Sheikh, 2005, p. 546), sedangkan menurut Imam Asy-Syaukani (Asy-Syaukani, n.d., p. 604) "bahwa supaya mereka mengakui penghambaan (mereka kepada-Nya), baik secara sukarela maupun terpaksa".

Maksud yang terkandung dalam ayat ini menurut Wahbah Al-Zuhaili adalah "Aku tidak menginginkan dari penciptaan mereka untuk menarik manfaat untuk-Ku dan tidak pula untuk menghalau mudharat dari-Ku seperti apa yang biasanya diinginkan oleh para majikan dari para budak mereka. Karena sesungguhnya Allah SWT adalah Dzat Yang Mahakaya Yang senantiasa memberi, Dzat Yang Maha Pemberi rezeki Yang memberi rezeki kepada semua makhluk-Nya dan menegakkan apa yang baik dan maslahat bagi mereka. Allah SWT adalah Dzat Yang mempunyai kekuasaan dan kekuatan, Dzat Yang Mahakukuh kekuatan-Nya. Allah SWT tidak menciptakan mereka untuk suatu manfaat yang mereka persembahkan kepada-Nya. Oleh karena itu, mereka haruslah melaksanakan apa yang menjadi maksud dan tujuan diciptakannya mereka, yaitu beribadah" (Az-Zuhaili, 2013, p. 77). Penegasan Allah dalam ayat ini adalah perintah beribadah yang merupakan amanah untuk dikerjakan. Karena tujuan jin dan manusia diciptakan adalah untuk beribadah, maka apapun yang dilakukan harus bernilai ibadah.

Adapun yang melatarbelakangi penelitian ini adalah firman Allah yang tercantum dalam Q.S. Al-Ahzab ayat 72 tentang beratnya menanggung dan menunaikan amanah, sehingga untuk mengerjakannya tidaklah mudah karena memerlukan sebuah konsep yang harus didukung oleh ilmu pengetahuan yang ada pada diri manusia. "Sesungguhnya Kami telah mengemukakan amanah kepada langit, bumi dan gunung-gunung, maka semuanya enggan untuk memikul amanah itu dan mereka khawatir akan mengkhianatinya, dan dipikullah amanah itu oleh manusia. Sesungguhnya manusia itu amat zalim dan amat bodoh".

Dalam ayat ini, Allah mengilustrasikan beratnya amanah sehingga langit, bumi, dan gunung pun tidak sanggup menerimanya, sementara manusia dengan kecerdasan akalnya mampu mengemban tanggung jawab amanah yang berat itu. Menurut Imam Asy-Syaukani dalam Tafsir Fathul Qadir, para mufassir berbeda pendapat mengenai amanat yang disebutkan di sini. Al Wahidi berkata, "Makna amanat di sini menurut semua mufassir adalah ketaatan dan pelaksanaan 
kewajiban-kewajiban yang pelaksanaannya terkait dengan pahala dan menyia-nyiakannya terkait dengan siksa". Pendapat lain diungkapkan Al Qurthubi bahwa "Amanat ini mencakup semua urusan agama" (Asy-Syaukani, n.d., p. 187 [9]).

Hal ini dipertegas dengan firman Allah bahwa menunaikan amanah itu harus didukung oleh pengetahuan dan pemahaman yang memadai, agar amanah yang sudah diberikan dapat dilaksanakan dengan baik dan dapat dipertanggungjawabkan. Penegasan itu terdapat dalam AlQur'an surat Al-Isra ayat 36.

"Dan janganlah kamu mengikuti apa yang kamu tidak mempunyai pengetahuan tentangnya. Sesungguhnya pendengaran, penglihatan dan hati, semuanya itu akan diminta pertanggungan jawabnya".

Begitu beratnya amanah itu, Rasulullah bersabda dalam sebuah hadis yang diriwayatkan oleh Bukhari dan Ahmad.

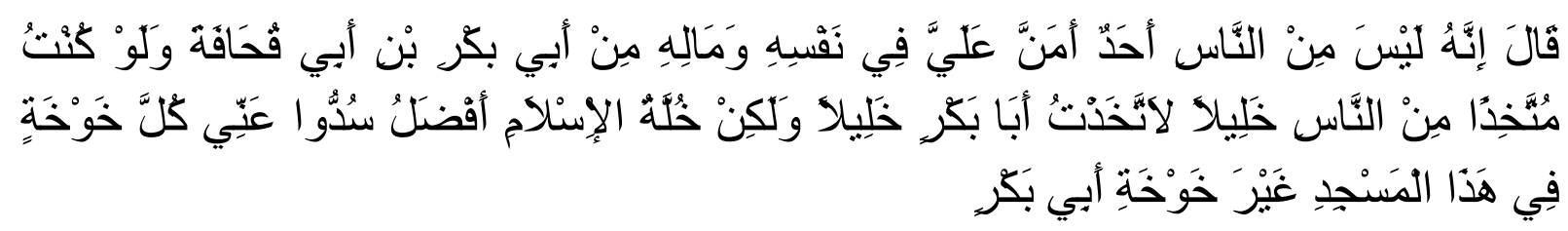

"Sesungguhnya tidak ada seorangpun yang paling amanah di hadapanku, baik pada dirinya maupun hartanya melebihi Abu Bakar bin Abu Quhafah. Seandainya aku boleh mengambil kekasih dari ummatku tentulah aku ambil Abu Bakar sebagai kekasihku. Akan tetapi persaudaraan Islam lebih utama. Tutuplah semua pintu dariku kecuali pintu Abu Bakar."(H.R. Bukhari dan Ahmad)

Amanah bisa dikatakan sebagai bentuk keharusan untuk bersikap profesional terhadap apa yang sudah diberikan Allah mencakup semua jenis profesi yang menempel pada diri manusia. Amanah adalah semua tugas atau pembebanan agama yang meliputi perkara dunia dan akhirat yang ditujukan kepada manusia atau segala yang diperintahkan Allah kepada hamba-Nya (Warson, 1997).

Untuk menegaskan dan meyakinkan bahwa begitu pentingnya amanah, Rasulullah SAW. pernah bersabda:

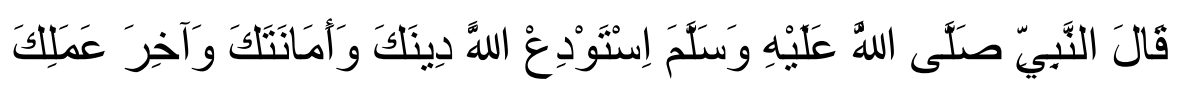

Artinya: “Aku titipkan kepada Allah agamamu, amanahmu dan akhir dari amalanmu” (H.R. Tirmidzi, Abu Daud dan Ahmad).

Dalam tema tentang amanah ini, terdapat beberapa artikel jurnal yang sudah dipublikasikan sebelumnya, yaitu artikel yang disusun oleh Abidin \& Khairudin (2017) dengan judul "Penafsiran Ayat-ayat Amanah dalam Al-Qur'an" yang membahas amanah sebagai kepercayaan yang merupakan tanggung jawab, sehingga saatnya harus dikembalikan kepada yang berhak. Kemudian, Buhori (2014) yang menyimpulkan amanah adalah sikap profesional dan memiliki relevansi dengan pendidikan Islam. Berkaitan dengan pembentukan karakter shiddiq dan amanah, Saifullah (2017) menjelaskan tentang pengendalian emosi dengan puasa sunat. Selanjutnya, Agung \& Husni (2017) membuat sebuah pengukuran konsep amanah dalam pendekatan kualitatif dan kuantitatif melalui penyebaran angket. Sementara itu, Sari \& Sofia (2018) membuat sebuah konstruksi alat ukur amanah dalam perspektif Al-Qur'an-Hadis. 
Penelitian-penelitian tersebut belum mengarah pada substansi dalam proses pendidikan Islam secara khusus, baru sebatas membahas definisi, macam, telaah tentang objek dan subjek yang menanggung amanah, hingga pengukuran yang parsial tidak secara komprehensif. Dalam penelitian ini, penulis akan membahas tentang konsep amanah dalam perspektif pendidikan Islam berdasarkan Al-Qur'an dan Hadis yang meliputi relevansi amanah dengan ilmu, amanah dalam profesi guru, dan amanah sebagai siswa. Alasan adanya relevansi antara amanah dan pendidikan Islam itu adalah karena pendidikan Islam merupakan amanah Allah karena menyangkut hak dan kewajiban yang harus dilaksanakan oleh makhluk-Nya. Sebagaimana Rasulullah bersabda "Menuntut ilmu adalah kewajiban bagi setiap muslim" (H.R. Ibnu Majah).

\section{Metode Penelitian}

Penelitian ini bersifat kepustakaan (Library Research), sehingga data yang diperoleh adalah berasal dari kajian teks atau buku-buku dan jurnal yang relevan dengan pokok masalah di atas. Library research memanfaatkan sumber perpustakaan untuk memperoleh data penelitiannya. Tegasnya, riset pustaka membatasi kegiatannya hanya pada bahan-bahan koleksi perpustakaan saja tanpa memerlukan riset lapangan. Riset pustaka tidak hanya sekedar urusan membaca dan mencatat literatur atau buku-buku sebagaimana yang sering dipahami banyak orang selama ini. Apa yang disebut riset pustaka, atau sering juga disebut studi pustaka, ialah rangkaian kegiatan yang berkenaan dengan metode pengumpulan data pustaka, membaca dan mencatat serta mengolah bahan penelitian (Hermawan, 2019).

Sebagaimana dalam Gambar 1, penelitian ini dilakukan dengan menganalisis beberapa ayat Al-Qur'an dan Hadis yang berkaitan dengan amanah sebagai data primer, kemudian dianalisis dengan menggunakan berbagai referensi tafsir dan kajian-kajian berupa jurnal sebagai data sekunder yang membahas tentang amanah tersebut secara umum, kemudian disimpulkan berdasarkan perspektif pendidikan Islam.

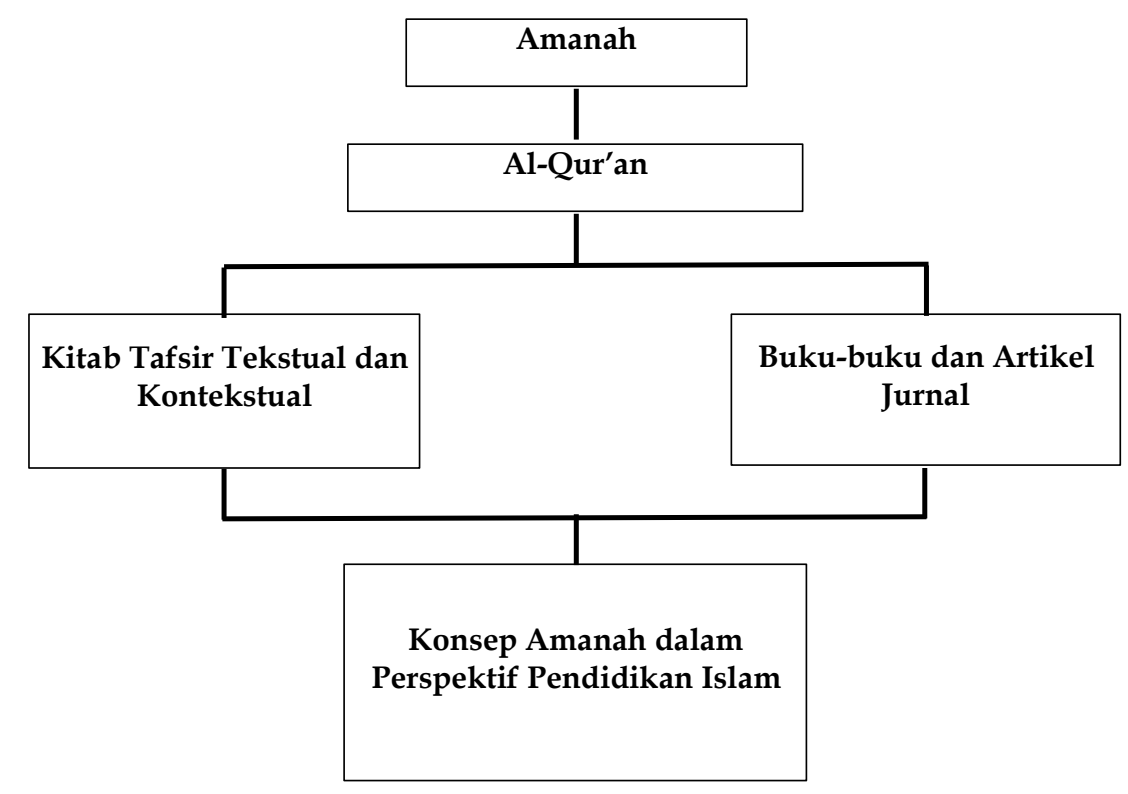

Gambar 1. Alur penelitian pustaka 
Untuk penelusuran hadis menggunakan aplikasi Haditssoft versi 4.0.0 berdasarkan teks dan konteks kemudian dianalisis berdasarkan kesesuaian tema dan maksud dari hadis tersebut untuk dapat disesuaikan dan diimplementasikan pada masa kini.

\section{Hasil dan Pembahasan}

\section{Pengertian Amanah}

Dalam Kamus Besar Bahasa Indonesia (KBBI), kata amanah mempunyai 3 (tiga) pengertian, yaitu: 1) sesuatu yang dipercayakan (dititipkan) kepada orang lain, 2) keamanan; ketenteraman, dan 3) dapat dipercaya (boleh dipercaya); setia (Pusat Bahasa Kemdikbud, 2011). Sedangkan dalam Ensiklopedi Al-Qur'an, kata amanah dimaksud adalah bentuk mashdar yang berasal dari kata kerja amina-ya 'manu-amnan-wa amanatan. Akar kata amanah terdiri dari huruf hamzah, mim, dan nun, yang berarti aman, tentram, tenang, dan hilangnya rasa takut (Shihab, 2007, p. 83). Amanah adalah sesuatu yang dipercaya, sedangkan amanat adalah pesan, perintah, wejangan. Kata amanah berasal dari bahasa Arab dan berkaitan dengan sifat seseorang yang dapat dipercaya atau sesuatu yang dipercayakan. Jika kita memahami amanat, sudah tentu kita menyadari amanah.

Amanah dapat menjadi indikator dari kekuatan iman seorang manusia, karena orang beriman akan dapat menjaga amanah dengan sebaik-baiknya, sedangkan orang yang imannya tipis, amanah yang ada pada dirinyapun ikut terkikis. Rasulullah SAW. bersabda:

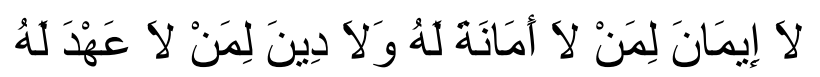

Artinya: "Tidak sempurna iman seseorang yang tidak amanah, dan tidak sempurna agama orang yang tidak menunaikan janji”.(HR. Ahmad).

\section{Konsep Amanah dalam Al-Qur'an dan Hadis}

Dalam Al-Quran terdapat enam kata amanah, yaitu Q.S. Al-Ahzab: 72, amanah sebagai tugas atau kewajiban; Q.S. Al-Baqarah: 283, amanah sebagai hutang atau janji yang harus ditunaikan; Q.S. An-Nisa':58, amanah sebagai tugas yang harus disampaikan pada yang berhak; Q.S. Al-Anfal: 27, tentang menjaga amanah; Q.S. Al-Mukminun: 8, anjuran memelihara amanah; dan Q.S. AlMa'arij: 32 anjuran memelihara amanah.

Sikap bertanggung jawab dan dapat dipercaya merupakan komponen-komponen amanah yang dapat terlihat dalam kehidupan seseorang dalam bermasyarakat. Amanah dapat menunjukan kualitas dan derajat keimanan seseorang. Amanah merupakan perbuatan yang paling substantif dalam kehidupan beragama Islam, karena amanah adalah implementasi dari iman (keyakinan), Islam (keselamatan), dan ihsan (kebaikan) yang tertuang dalam kehidupan manusia pada aspek vertikal (habl min Allah) dan aspek horizontal (habl min an-nas).

Dengan mengimplementasikan amanah yang sesuai dengan klausul perintah dan larangan dari Allah, maka manusia akan terselamatkan kehidupannya, baik di dunia maupun akhirat, karena dia telah membawa keselamatan bagi dirinya sendiri dan orang lain. Jika manusia yang menunaikan amanah Allah disebut manusia yang beriman maka manusia yang tidak amanah terhadap perintah dan larangan Allah disebut khianat. Khianat adalah dosa besar yang sangat dibenci oleh Allah, sebagaimana firman-Nya dalam Al-Qur'an Surat Al-Anfal ayat 27: "Hai orang-orang yang beriman, 
janganlah kamu mengkhianati Allah dan Rasul (Muhammad) dan (juga) janganlah kamu mengkhianati amanat-amanat yang dipercayakan kepadamu, sedang kamu mengetahui”.

Dalam pandangan syari'at Islam, amanah mengandung makna yang amat luas yang meliputi perasaan manusia untuk melaksanakan segala sesuatu yang dibebankan kepadanya berdasarkan kesadaran dan tanggung jawab dirinya kepada Allah. Amanah selalu berkaitan dengan lisan dan perbuatan, karena kunci amanah adalah menjaga dan menyampaikan segala sesuatu yang sudah dititipkan kepadanya terkait urusan agama maupun umum, urusan dunia ataupun akhirat. Sebagaimana firman Allah yang terdapat dalam Q.S Al-Mu'minun: 8 dan Q.S. Al-Ma'arij: 32: "Dan orang-orang yang memelihara amanat-amanat (yang dipikulnya) dan janjinya."

Pada ayat ini, Ibnu Katsir menafsirkan orang amanah adalah jika mereka diberi kepercayaan, maka mereka tidak mengkhianatinya tetapi mereka menunaikannya kepada yang berhak (Al-Sheikh, 2005, p. 527 [5]). Orang amanah adalah apabila mereka dititipkan sesuatu tidak berkhianat, ketika berjanji tidak melanggar, jika sebaliknya adalah sifat-sifat orang munafik (Ar-Rifa'i, 2000, p. 812 [4]). Mereka tidak berkhianat dengan amanah yang dititipkan kepadanya dan mereka tidak mengingkari janji yang sudah diucapkannya (Al-Maraghi, 1989, p. 128 [29]). Mereka akan menjaga amanah yang mereka emban serta tidak pernah membatalkan dan melanggar janji-janji yang mereka buat (Al-Qarni, 2007, p. 426).

Lawan dari sifat amanah adalah sifat khianat, dan sifat khianat itu adalah termasuk perbuatan orang-orang munafik, sebagaimana Rasulullah bersabda:

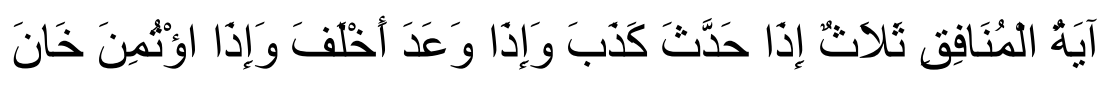

Artinya: "Tanda-tanda orang munafik itu ada tiga, yaitu jika berbicara berdusta, jika berjanji mengingkari dan jika dipercaya berkhianat." (H.R. Bukhari, Muslim, Tirmidzi dan Nasa'i)

Dalam hadis yang lain Rasulullah memberikan penegasan tentang amanah dan pengkhianatan.

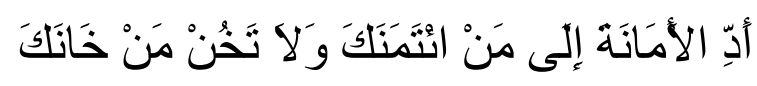

Artinya: "Tunaikanlah amanah kepada orang yang mempercayaimu, dan jangan kamu khianat kepada orang yang mengkhianatimu." (H.R. Abu Daud)

Kendati demikian, manusia sebagai makhluk yang dibebani amanah, dalam kenyataannya tidak selalu dapat menjaga dan menunaikan amanah. Hal itu dapat terlihat dari banyaknya penyelewengan, seperti korupsi, kolusi, manipulasi, suap, tidak bertanggungjawab, dan menyianyiakan kepercayaan. Pemandangan seperti itu seolah menjadi biasa di mata manusia, seakan-akan hal tersebut bukanlah pelanggaran amanah padahal kemampuan menjaga amanah tetaplah bersumber dari hidayah dan bimbingan Allah.

"Sesungguhnya Allah menyuruh kamu menyampaikan amanat kepada yang berhak menerimanya, dan (menyuruh kamu) apabila menetapkan hukum di antara manusia supaya kamu menetapkan dengan adil. Sesungguhnya Allah memberi pengajaran yang sebaik-baiknya kepadamu. Sesungguhnya Allah adalah Maha Mendengar lagi Maha Melihat.” (Q.S. An-Nisa: 58)

Dalam tafsir Ibnu Katsir disebutkan bahwa hal tersebut mencakup seluruh amanah yang wajib bagi manusia, berupa hak-hak Allah terhadap para hamba-Nya, seperti shalat, zakat, puasa, kafarat, nazar, dan selain dari itu, yang kesemuanya adalah amanah yang diberikan tanpa pengawasan 
hamba-Nya yang lain. Serta amanah yang berupa hak-hak sebagian hamba dengan hamba lainnya, seperti titipan dan selanjutnya, yang kesemuanya adalah amanah yang dilakukan tanpa pengawasan saksi. Itulah yang diperintahkan oleh Allah untuk ditunaikan. Barangsiapa yang tidak melakukannya di dunia ini, maka akan dimintai pertanggungjawabnya di hari kiamat (Al-Sheikh, 2005, p. 336 [2]).

Tujuan Allah membebankan amanah kepada manusia adalah sebagai alat ukur keimanan dan derajat manusia. Manusia yang dapat menuaikan amanah derajatnya lebih tinggi daripada makhlukmakhluk yang lain termasuk malaikat. Namun, jika manusia tidak dapat menunaikan amanah yang dibebankan oleh Allah, maka manusia tersebut mempunyai iman yang lemah dan derajatnya lebih rendah daripada binatang.

Berdasarkan penelaahan konseptual diperoleh karakteristik sifat dan perilaku yang amanah berdasarkan Al-Qur'an dan Hadis, serta beberapa sumber rujukan lainnya. Karakteristik tersebut kemudian digunakan peneliti sebagai acuan dalam pembuatan indikator-indikator amanah (Sari \& Sofia, 2018).

Kendati demikian amanah dapat diukur berdasarkan pendekatan kualitatif maupun kuantitatif bahwa 1) prototipe orang amanah adalah orang yang memiliki karakter positif, seperti dapat dipercaya, bertanggung jawab dan jujur, dan orang yang mampu melaksanakan tugas yang diberikan, dan 2) komponen dalam skala amanah yatu integritas, melaksanakan tugas dan kebajikan (Agung \& Husni, 2017).

Dengan demikian, amanah dapat dirumuskan sebagai kewajiban hamba kepada Allah yang harus dikerjakan sebagai karakter terpuji untuk kebaikan dirinya sendiri, orang lain dan alam sekitarnya.

\section{Relevansi Konsep Amanah dengan Pendidikan Islam}

\section{Relasi Amanah dengan Ilmu}

Dalam Undang-Undang Republik Indonesia nomor 20 tahun 2003 tentang Sistem Pendidikan Nasional, pada bab I pasal 1 ayat 1 disebutkan bahwa pendidikan adalah usaha sadar dan terencana untuk mewujudkan suasana belajar dan proses pembelajaran agar peserta didik secara aktif mengembangkan potensi dirinya untuk memiliki kekuatan spiritual keagamaan, pengendalian diri, kepribadian, kecerdasan, akhlak mulia, serta keterampilan yang diperlukan dirinya, masyarakat, bangsa, dan negara. Kalimat "mengembangkan potensi dirinya untuk memiliki kekuatan spiritual keagamaan" adalah amanah untuk mencari dan menyampaikan ilmu yang bukan hanya sebatas pengetahuan tapi harus diimplementasikan dalam kehidupannya sehari-hari berupa sikap dan karakter.

Ilmu adalah amanah yang harus ditunaikan dan dipertanggungjawabkan oleh yang mengembannya. Menuntut ilmu dan menyebarkan ilmu adalah amanah kepada dirinya sendiri dan amanah pada perintah Allah. Dengan konsep amanah itulah problematika-problematika dalam pendidikan Islam dapat teratasi.

Wardi (2013) menyebutkan problematika yang sangat kompleks dalam pendidikan Islam, yaitu:

a. Pendidikan Islam berkesan sebagai pendidikan yang tradisional dan konservatif, hal ini wajar karena orang memandang bahwa kegiatan pendidikan Islam dihinggapi oleh 
lemahnya penggunaan metodologi pembelajaran yang cenderung tidak menarik perhatian dan memberdayakan.

b. Pendidikan Islam kurang concern terhadap persoalan bagaimana mengubah pengetahuan agama yang bersifat kognitif menjadi suatu "makna dan nilai" yang perlu diinternalisasikan dalam diri seseorang lewat berbagai cara, media, dan forum.

c. Metodologi pengajaran agama berjalan secara konvensional/tradisional, yakni menitikberatkan pada aspek korespondensi tekstual yang lebih menekankan yang sudah ada pada kemampuan anak didik untuk menghafal teks-teks keagamaan daripada isu-isu sosial keagamaan yang dihadapi pada era modern seperti kriminalitas, kesenjangan sosial dan lain lain.

d. Pengajaran agama yang bersandar pada bentuk metodologi yang bersifat statis indoktrinatif-doktriner.

Berdasarkan pada hal tersebut di atas, maka diperlukan sebuah konsep, model, metode, dan strategi dari pengembangan ilmu agama secara khusus. Pengembangan tersebut harus didasarkan pada perbaikan dan kelangsungan hidup manusia untuk menjadi khalifah sebagai amanah besar dari Allah. Dengan demikian, teknologi yang lahir dari ilmu akan menjadi barang yang bermanfaat bagi umat manusia di sepanjang masa.

Sebagaimana persepsi umum bahwa ilmu merupakan salah satu amanah yang benarbenar harus ditunaikan karena kelak akan dimintai pertanggungjawaban. "Barangsiapa yang menempuh jalan untuk menuntut ilmu, Allah Ta'ala akan memudahkan baginya jalan menuju surga.” (HR. Muslim, Tirmidzi dan Ahmad).

Ilmu adalah amanah yang harus ditunaikan oleh orang yang mempunyai ilmu (pendidik) atau orang yang sedang mencari ilmu (peserta didik) karena berniat ibadah kepada Allah sebagaimana tercantum dalam Q.S. Al-Mujadilah ayat 11. Ilmu yang baik adalah ilmu yang berada dalam kontrol iman sehingga manfaat ilmu tersebut untuk dapat dirasakan karena pengembangannya didasarkan pada perbaikan dan kelangsungan hidup manusia untuk menjadi khalifah di muka bumi ini. Allah juga secara khusus mengangkat dan meninggikan kedudukan para ulama dengan beberapa derajat yang tinggi dalam hal kehormatan dan kemuliaannya di dunia serta dalam hal pahala di akhirat (Az-Zuhaili, 2013, p. 416).

Tanpa pendidikan, manusia tidak akan memperoleh ilmu, tanpa ilmu ia tidak akan dapat beriman, beribadah dan bertakwa dengan baik sesuai perintah pertama dan kehendak Allah yang terdapat dalam Q.S. Al-Alaq: 1-5. Sebagaimana ucapan Ibnu Qayyim Al-Jauziyah (2012, p. 89) "Ilmu itu adalah kehidupan dan cahaya, sedangkan kebodohan adalah kematian dan kegelapan. Seluruh kejelekan terjadi dengan sebab tidak adanya kehidupan dan cahaya, sedangkan seluruh kebaikan terjadi disebabkan oleh cahaya dan kehidupan”.

\section{Amanah dalam Profesi Guru}

Menjadi guru adalah amanah yang amat mulia, karena guru adalah seseorang yang diutus Allah untuk memberi pengetahuan kepada manusia di dunia ini, guru adalah orang yang diberi amanah oleh Allah untuk mengajar dan mendidik manusia di dunia ini, maka mulialah seorang guru yang bisa mengemban amanah ini, guru juga adalah penunjuk ke jalan kebaikan, menjadi seorang guru adalah ibadah yang disyariatkan oleh Allah karena seorang 
guru senantiasa menyebarkan kebaikan dan membimbing murid untuk menjadi lebih baik dan benar.

Amanat yang diemban oleh guru dalam Pasal 1 UU No. 23 Tahun 2017 disebutkan bahwa guru adalah pendidik profesional dengan tugas utama mendidik, mengajar, membimbing, mengarahkan, melatih, menilai, dan mengevaluasi peserta didik pada pendidikan anak usia dini jalur pendidikan formal, pendidikan dasar, dan pendidikan menengah. Tugas seorang guru bukan hanya sekedar mentransfer knowledge (pengetahuan) kepada siswa, namun untuk mendidik siswa dengan memberikan pengalaman-pengalaman belajar yang menarik, sehingga mereka mampu membedakan benar dan salah. Guru juga memiliki kewajiban membimbing siswa, dari yang tidak tahu menjadi tahu, dan dari yang tidak bisa menjadi bisa, serta dari yang salah menuju benar. Menjadi seorang guru tidak boleh menghakimi seorang siswa yang dianggap nakal, tidak sopan, kurang cerdas, karena tugas guru adalah menilai dan mengevaluasi siswanya, baik secara kognitif, afektif, maupun psikomotoriknya kemudian membimbing dan mengarahkan mereka untuk menjadi orang yang lebih baik.

Guru merupakan profesi atau pekerjaan profesional yang membutuhkan pendidikan dan pelatihan, sehingga profesi tersebut bukanlah profesi biasa yang semua orang dapat melakukannya. Guru yang profesional tentunya akan mampu melaksanakan amanah keprofesiannya sesuai dengan tupoksi (tugas, pokok, dan fungsi)-nya, sekaligus tempat ia menggantungkan hidupnya. Sosok inilah yang diharapkan oleh masyarakat secara umum untuk menempati posisi yang istimewa dan terhormat dan selalu disandarkan harapan-harapan yang tinggi terhadapnya. Sebab sejatinya seorang guru adalah mereka yang memiliki kesadaran diri dalam keprofesiannya. Kalaupun ada niatan yang menyimpang, maka tidak lain hanyalah oknum tertentu, sehingga tidak boleh guru dijustifikasi secara umum dalam keprofesian telah melakukan pelanggaran.

Menurut Pasal 2 UU No. 14 Tahun 2005, guru mempunyai kedudukan sebagai tenaga profesional pada jenjang pendidikan dasar, pendidikan menengah, dan pendidikan anak usia dini pada jalur pendidikan formal yang diangkat sesuai dengan peraturan perundangundangan. Selain itu dijelaskan pula dalam pasal 6 bahwa kedudukan guru sebagai tenaga profesional bertujuan untuk melaksanakan sistem pendidikan nasional dan mewujudkan tujuan pendidikan nasional, yaitu berkembangnya potensi peserta didik agar menjadi manusia yang beriman dan bertakwa kepada Tuhan Yang Maha Esa, berakhlak mulia, sehat, berilmu, cakap, kreatif, mandiri, serta menjadi warga negara yang demokratis dan bertanggung jawab.

Dalam sebuah hadis Nabi, tersurat kisah berikut:

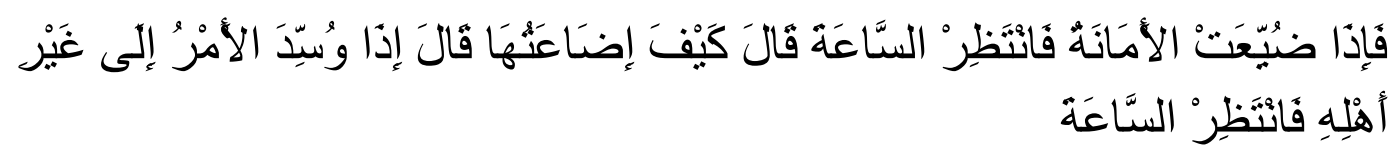

Artinya: "Apabila sudah hilang amanah maka tunggulah terjadinya kiamat." mereka bertanya: "Bagaimana hilangnya amanah itu?" Nabi shallallahu 'alaihi wa sallam menjawab: "Jika urusan diserahkan bukan kepada ahlinya, maka tunggulah terjadinya kiamat."(H.R. Bukhari) 


\section{Amanah sebagai Pelajar dan Masyarakat Awam}

Seorang pelajar atau penuntut ilmu sangat memerlukan sikap jujur dan amanah dalam proses pembelajarannya, agar hasil yang didapatnya bukan sekedar pengetahuan semata tapi mengubah sikap dan perilakunya menjadi lebih baik. Antara siswa dan guru memiliki hak dan kewajiban seperti mata uang, dimana setiap sisinya saling melengkapi dan merupakan satu kesatuan. Artinya, hak seorang siswa adalah kewajiban seorang guru dan kewajiban seorang siswa adalah hak seorang guru. Keduanya memiliki hak dan kewajiban yang sama dalam rangka menaati perintah Allah sebagaimana yang terkandung dalam Q.S. Luqman ayat 13-19 (Sifa, 2020).

Konsep pendidik dalam pendidikan Islam sendiri dirumuskan berdasarkan sudut pandang Islam yang sesuai dengan ajaran Islam, dan bukan hanya sekedar memberikan bekal pengetahuan, keterampilan, keimanan, dan ketakwaan saja, tetapi juga harus diarahkan pada upaya melahirkan manusia kreatif, inovatif, mandiri, dan produktif, mengingat dunia yang akan datang adalah dunia yang kompetitif (Nata, 2001, p. 97). Dengan demikian pendidik adalah sosok yang membawa amanah, menjaga, dan melaksanakannya sebagai panggilan Tuhan. Sementara, peserta didik ialah makhluk memiliki potensi fitrah dan menggunakannya dalam kegiatan belajar mengajar agar berkembang optimal sehingga siap membangun kebudayaan dan peradaban.

Memiliki sifat amanah dapat menuntun seseorang menjadi pribadi yang lebih baik. Oleh karena itu penanaman karakter amanah sepatutnya dimulai saat seseorang masih kecil atau pada usia dini. Sebab anak merupakan kertas putih yang akan menjadi sesuatu sesuai dengan apa yang dipelajarinya semenjak kecil (Saifullah, 2017).

Amanah adalah kepercayaan yang diberikan oleh Allah atau makhluk lain untuk dilaksanakan oleh orang yang diberi amanah yang meliputi malaikat, jin dan manusia, atau bahkan alam semesta. Amanah yang datang dari Allah terkait dengan segala bentuk perintah dan larangan yang dibebankan kepada manusia. Sedangkan amanah dari manusia terkait dengan segala bentuk kepercayaan, baik dalam bentuk harta benda, jabatan dan rahasia.

Amanah kepada sesama manusia berupa sesuatu yang dipercayakan, baik material maupun non-material untuk memberikan rasa aman dan tenteram. Amanah kepada diri sendiri adalah mengimplementasikan seluruh nikmat yang diberikan menjadi bentuk lisan dan perbuatan dalam penghambaan dirinya kepada Allah. Amanah adalah salah satu bukti keimanan seseorang, dan bagi mereka yang tidak bisa menjaga dan menunaikan amanah, adalah termasuk pada golongan orang-orang yang tidak beriman.

\section{Kesimpulan}

Konsep amanah yang terdapat dalam Al-Qur'an mengandung pengertian yang sangat komprehensif, mencakup hubungan manusia dengan dirinya sendiri dan orang lain, hubungan manusia dengan Tuhannya, serta hubungan manusia dengan alam sekitarnya. Amanah yang dibebankan oleh Allah kepada manusia mengandung arti bahwa derajat manusia lebih tinggi dibanding makhluk lainnya. Manusia diberikan kepercayaan sebagai makhluk yang paling sempurna dengan mengemban amanah yang tidak mungkin bisa dilakukan oleh makhluk lain. 
Enam kata perintah amanah yang terdapat dalam Q.S. Al-Ahzab: 72, Q.S. Al-Baqarah: 283, Q.S. An-Nisa': 58, Q.S. Al-Anfal: 27, Q.S. Al-Mukminun: 8, dan Q.S. Al-Ma'arij: 32 adalah penegasan Allah tentang pentingnya menjaga amanah pada seluruh aspek kehidupan manusia, termasuk pada ranah pendidikan. Karena amanah merupakan kewajiban yang dibebankan Allah kepada manusia, jika pendidik dan peserta didik menunaikan amanahnya secara baik, maka yang didapat bukan hanya kualitas yang baik tapi juga pada pemenuhan kewajiban yang merupakan ibadah kepada Allah.

Menjadi pendidik adalah amanah Allah untuk menyampaikan ilmu pengetahuan agar yang menerima ilmu mampu menjadi manusia yang dapat mengemban amanah dari Allah berupa ilmu pengetahuan untuk kepentingan kehidupan manusia sebagai khalifah di muka bumi. Menjadi peserta didik adalah amanah Allah untuk belajar agar mendapatkan ilmu pengetahuan yang dapat mengangkat derajat manusia lebih tinggi dibanding dengan makhluk yang lain.

Perintah Allah adalah amanah untuk manusia sehingga tidak akan mungkin ditunaikan apabila tidak dibarengi dengan ilmu. Pendidik sebagai penyampai ilmu dan peserta didik sebagai penerima ilmu, dengan penuh kejujuran serta diiringi rasa takut kepada Allah merupakan sebuah amanah yang harus ditunaikan dan dipertanggungjawabkan.

Terdapat relevansi antara amanah dengan pendidikan Islam dimulai dari input yang didasari pada perintah Allah yang pertama kali diturunkan kepada Nabi Muhammad untuk manusia yaitu sebagaimana terdapat dalam Q.S. Al-Alaq: 1-5 yang dimulai dari membaca, menulis berdasarkan ajaran Allah dalam Al-Qur'an yang melandasi ilmu pengetahuan tentang agama yang dijelaskan oleh Hadis serta ijtihad para ulama. Kemudian ilmu tersebut diproses dalam bentuk pembelajaran yang merupakan kewajiban sepanjang hayat dan akan menjadi kebutuhan dasar dan bekal untuk menjalani kehidupan sebagai manusia yang berakal. Selanjutnya dari hasil proses itu menghasilkan output yang berupa pengetahuan yang merupakan amanah yang harus dijaga dan disampaikan melalui sikap akhlak karimah, beriman dan bertakwa kepada Allah dan diimplementasikan dalam bentuk ibadah, karena ibadah yang tidak didasari oleh ilmu adalah sia-sia, sebagaimana firman Allah dalam Al-Qur'an surat Al-Isra ayat 36: "Dan janganlah engkau ikuti apa yang engkau tidak mempunyai ilmu tentangnya, sesungguhnya pendengaran, penglihatan dan hati semuanya itu akan ditanya".

\section{Daftar Pustaka}

Abidin, Z., \& Khairudin, F. (2017). Penafsiran Ayat-Ayat Amanah Dalam Al-Qur'an. Jurnal

Syahadah $\quad V o l ., \quad V$
http://ejournal.fiaiunisi.ac.id/index.php/syahadah/article/view/188/157

Agung, I. M., \& Husni, D. (2017). Pengukuran Konsep Amanah dalam Pendekatan Kualitatif dan Kuantitatif. Jurnal Psikologi, 43(3), 194. https://doi.org/10.22146/jpsi.11233

Al-Jauziyah, I. Q. (2012). Miftah Daris Sa'adah: Kunci Kebahagiaan di Dunia dan Akhirat (I. Firdaus (ed.)). Pustaka Imam Syafi'i.

Al-Maraghi, A. M. (1989). Terjemah Tafsir Al-Maraghi (A. B. Bahrun \& A. H. Noer (eds.); 29th ed.). CV. Toha Putra.

Al-Qarni, A. (2007). Tafsir Muyassar (4th ed.). Qisti Press.

Al-Sheikh, A. bin M. bin A. bin I. (2005). Tafsir Ibnu Katsir [1-8] (A. Ghoffar (ed.)). Pustaka 
Imam Syafi'i.

Ar-Rifa'i, M. N. (2000). Ringkasan Tafsir Ibnu Katsir Jilid 4. Gema Insani Press.

Asy-Syaukani, M. ibn A. ibn M. (n.d.). Tafsir Fathul Qadir [1-12] (S. Ibrahim (ed.)). Pustaka Azzam.

Az-Zuhaili, W. (2013). Tafsir Al-Munir [1-15] (A. H. Al-Kattani (ed.); 1st ed.). Gema Insani Press.

Buhori. (2014). Nilai-nilai Pendidikan Amanah dalam Al-Quran. Jurnal Madania, 4.

Hamka, H. A. M. A. K. A. (1982). Tafsir Al-Azhar [1-10]. Pustaka Nasional PTE LTD.

Hermawan, I. (2019). Metodologi Penelitian Pendidikan (Kualitatif, Kuantitatif dan Mixed Method). Hidayatul Quran. https://books.google.co.id/books?id=Vja4DwAAQBAJ

Nata, A. (2001). Perspektif Islam Tentang Pola Hubungan Guru-Murid (1st ed.). Raja Grafindo Persada.

Pusat Bahasa Kemdikbud. (2011). Kamus Besar Bahasa Indonesia. Pusat Bahasa Departemen Pendidikan Nasional. http://www.kamusbesar.com/38643/surealisme

Saifullah. (2017). Konsep Pembentukan Karakter Siddiq dan Amanah pada Anak melalui Pembiasaan Puasa Sunat. Jurnal Mudarrisuna: Media Kajian Pendidikan Agama Islam, 7(1), 77-102. https://doi.org/10.22373/jm.v7i1.1910

Sari, E. P., \& Sofia, N. (2018). Konstruksi Alat Ukur Amanah dalam Perspektif al-Qur 'an-Hadis. Jurnal Psikologi Islam, 5(1), 13-26. http://jpi.api-himpsi.org/index.php/jpi/article/view/55

Shihab, M. Q. (2007). Ensiklopedi Al-Qur'an, Kajian Kosakata. Lentera Hati.

Sifa, A. N. A. (2020). Hak dan Kewajiban Guru dan Siswa dalam QS Luqman Ayat 13-19. QALAMUNA: Jurnal Pendidikan, Sosial, Dan Agama, 12(01), 79-90. https://doi.org/10.37680/qalamuna.v12i01.328

Wardi, M. (2013). Problematika Pendidikan Islam dan Solusi Alternatifnya (Perspektif Ontologis, Epistemologis dan Aksiologis). Tadris: Jurnal Pendidikan Islam, $8(1)$. https://doi.org/http://dx.doi.org/10.19105/jpi.v8i1.383

Warson, M. A. (1997). Kamus Al-Munawir Arab-Indonesia Terlengkap. Pustaka Progresif. 